\title{
Mouthwash with Tagetes lucida Cav. for Control of Chronic Periodontitis in Older Adults
}

\author{
Thalia Macías-Camacho ${ }^{1}$, Raquel Retana-Ugalde ${ }^{1,2, *}$, Martha Legorreta-Herrera ${ }^{3}$ D, Mirna Ruiz-Ramos ${ }^{2}$ \\ and Víctor Manuel Mendoza-Núñez ${ }^{2}$ (D) \\ 1 Posgrado en Ciencias Biológicas, Universidad Nacional autónoma de México (UNAM), \\ Ciudad de México 09230, Mexico; medtradic@yahoo.com.mx \\ 2 Unidad de Investigación en Gerontología, Facultad de Estudios Superiores Zaragoza, Universidad Nacional \\ Autónoma de México (UNAM), Ciudad de México 09230, Mexico; mirna1411@yahoo.com.mx (M.R.-R.); \\ mendovic@unam.mx (V.M.M.-N.) \\ 3 Laboratorio de Inmunología Molecular, Facultad de Estudios Superiores Zaragoza, Universidad Nacional \\ Autónoma de Mexico (UNAM), Ciudad de México 09230, Mexico; marthal@unam.mx \\ * Correspondence: retanara@unam.mx; Tel.: +52-(55)-5623-0766
}

Citation: Macías-Camacho, T.; Retana-Ugalde, R.; Legorreta-Herrera, M.; Ruiz-Ramos, M.; Mendoza-Núñez, V.M. Mouthwash with Tagetes lucida Cav. for Control of Chronic Periodontitis in Older Adults. Sustainability 2021,

13, 1650. https://doi.org/

$10.3390 /$ su13041650

Academic Editor: Serik Meirmanov Received: 7 December 2020

Accepted: 28 January 2021

Published: 4 February 2021

Publisher's Note: MDPI stays neutral with regard to jurisdictional claims in published maps and institutional affiliations.

Copyright: (c) 2021 by the authors. Licensee MDPI, Basel, Switzerland. This article is an open access article distributed under the terms and conditions of the Creative Commons Attribution (CC BY) license (https:/ / creativecommons.org/licenses/by/ $4.0 /)$.

\begin{abstract}
Background: Tagetes lucida Cav (T. lucida) is an herbaceous plant from the family Asteraceae, native to Mexico, Guatemala, and other Mesoamerican countries. Their common names are: (i) Spanish names: "hierbanís", "jericón", "pericón vomol”, "Santa María", “cuchrucumín”, "falso hipericón", “hierba añil", "pericón”, "periquillo"; (ii) indigenous names: "ichka”, "cuahuyauhtli”, "yahuhtli", "naná uarhi", and (iii) English names: "sweet-scented marigold", "sweet mace", and "sweet marigold"., Its chemical composition of coumarins, estragole, quercetin, and flavonoids has antioxidant, anti-inflammatory, and antimicrobial effects. This study aimed to evaluate the effect of a mouthwash made with T. lucida for control of chronic periodontitis (CP) in older adults. Methods: We carried out a quasi-experimental study with a convenience sample of 60 older adults with CP. The sample was divided into a placebo group (PG) $n=30$, administered with a mouthwash made with alcohol diluted with purified water (10\%), and the experimental group (EG) $n=30$ treated with a mouthwash made with T. lucida extract in 10\% alcohol; both groups were administered three times a day for three months. Results: We found a significant improvement in the EG group compared with the PG group in: probing pocket depth (baseline, $5.2 \pm 0.81$ vs. post-treatment, $3.1 \pm 0.43, p<0.05$ ), the clinical attachment loss (baseline, $6.6 \pm 1.9$ vs. post-treatment, $2.1 \pm 1.5, p<0.05$ ), lipoperoxides (baseline, $0.056 \pm 0.03$ vs. post-treatment, $0.034 \pm 0.02 \mu \mathrm{mol} / \mathrm{L}, p<0.05$ ), and chronic inflammation markers (IL-1, IL-8, and TNF- $\alpha)(p<0.05)$. Conclusions: Our findings suggest that mouthwash made with T. lucida extract, administered three times a day, clinically improved chronic periodontitis in older adults, associated to a significant decrease in lipoperoxides and proinflammatory markers.
\end{abstract}

Keywords: chronic periodontitis; Targetes lucida Cav.; older adults; oxidative stress; inflammation

\section{Introduction}

Chronic periodontitis (CP) is a multifactorial disease, which is associated with the activation of polymorphonuclear leukocytes. Consequently, it generates a high concentration of reactive oxygen species (ROS) and a decrease in the antioxidant system, which causes oxidative stress in the periodontal tissue [1-4]. CP has a high prevalence and incidence in the world; in Mexico it occurs in more than $70 \%$ of the older adult population ( $\geq 60$ years) $[5,6]$.

If this biochemical disorder is maintained, the epithelial adhesion is destroyed and the alveolar crest loses its height, which translates clinically into dental mobility and formation of periodontal pockets, causing the accumulation of bacteria that increases the inflammation, destroying the periodontal ligament, and consequently, the alveolar bone atrophies, and the tooth is lost. This disease is associated with the activation of 
polymorphonuclear leukocytes, which in turn can generate a high concentration of reactive oxygen species (ROS) and a decrease in the antioxidant system, which causes oxidative stress in the tissue periodontal [1-4]. It has been observed that CP has a high prevalence and incidence in the world; in Mexico it occurs in more than $70 \%$ of the population of older adults $[5,6]$.

To avoid the damage related to $\mathrm{CP}$, conventional treatment focuses on stopping the progression of periodontal tissue destruction by eliminating local factors through oral hygiene instructions combined with scaling and root smoothing, to maintain and/or restore the function and aesthetics [5]. However, even when this treatment is carried out rigorously, the results are not entirely satisfactory. For this reason, various ethnobotanical therapies have been developed in the treatment of CP, with favorable effects [7-9].

In this context, we propose that Tagetes lucida could be useful as a therapeutic option for $\mathrm{CP}$, considering its chemical composition of coumarins, estragole, and quercetin, with antioxidant, anti-inflammatory and antimicrobial effects [10,11].

T. lucida is an herbaceous plant from the family Asteraceae, native to Mexico, Guatemala, and other Mesoamerican countries, with a self-supporting growth habit, size up to $80 \mathrm{~cm}$ tall, usually several branched stem, simple leaves, and yellow flowers. Its common names are: (i) in Spanish: "hierbanís", "jericón", "pericón vomol" "Santa María" "cuchrucumín", "falso hipericón", "hierba añil", "pericón", and "periquillo"; and (ii) its indigenous names are "ichka", "cuahuyauhtli", "yahuhtli", and "naná uarhi". In English, it is known as: "sweet-scented marigold", "sweet mace", or "sweet marigold". This plant is registered at the FES Zaragoza Herbarium UNAM (No 156999) and the U.S. FDA Unique Ingredient Identifier (UNII: N4052J8NFR) [12,13].

Experimentally, it has been shown that T. lucida has antifungal and antibacterial properties. Additionally, it has tranquillizing, antidepressant activity, as well as antiinflammatory and antioxidant activities [14-19]. Therefore, this study aimed to evaluate the impact of T. lucida on oxidative stress and chronic periodontitis in older adults.

\section{Materials and Methods}

\subsection{Subjects and Design}

After informed consent, a quasi-experimental, double-blind study was conducted in 60 older adults, 17 (28\%) men and 43 (72\%) women with an average age of $68 \pm 6.52$, who attended the odontology service at Zaragoza Clinic, UNAM. They had controlled chronic non-communicable diseases, without consumption of antioxidant supplements in the last 6 months, all with clinical diagnosis of periodontal disease. The patients were not under periodontal treatment or used a supplement for oral cleaning, no change was made in their hygienic and dietary habits. The Ethics Committee of the Universidad Nacional Autónoma de México (UNAM), Zaragoza Campus approved the research protocol (FESZ/DEPI/325/16).

Subsequently, a clinical evaluation for the diagnosis of CP was achieved by the following parameters: the depth and presence of bleeding on probing, the level of clinical insertion, and the presence of tooth mobility.

For the study, a convenience sample of 60 subjects who met the inclusion criteria were randomly divided into 2 groups, the placebo group (PG, $n=30$ ) was administered mouthwash of absolute alcohol (10\%) in purified water and the experimental group (EG, $n=30)$ was treated with a mouthwash treatment based on the extract of T. lucida (10\%), 3 times a day for 3 months (5 mL every $8 \mathrm{~h}$ ) (Figure 1 ). 


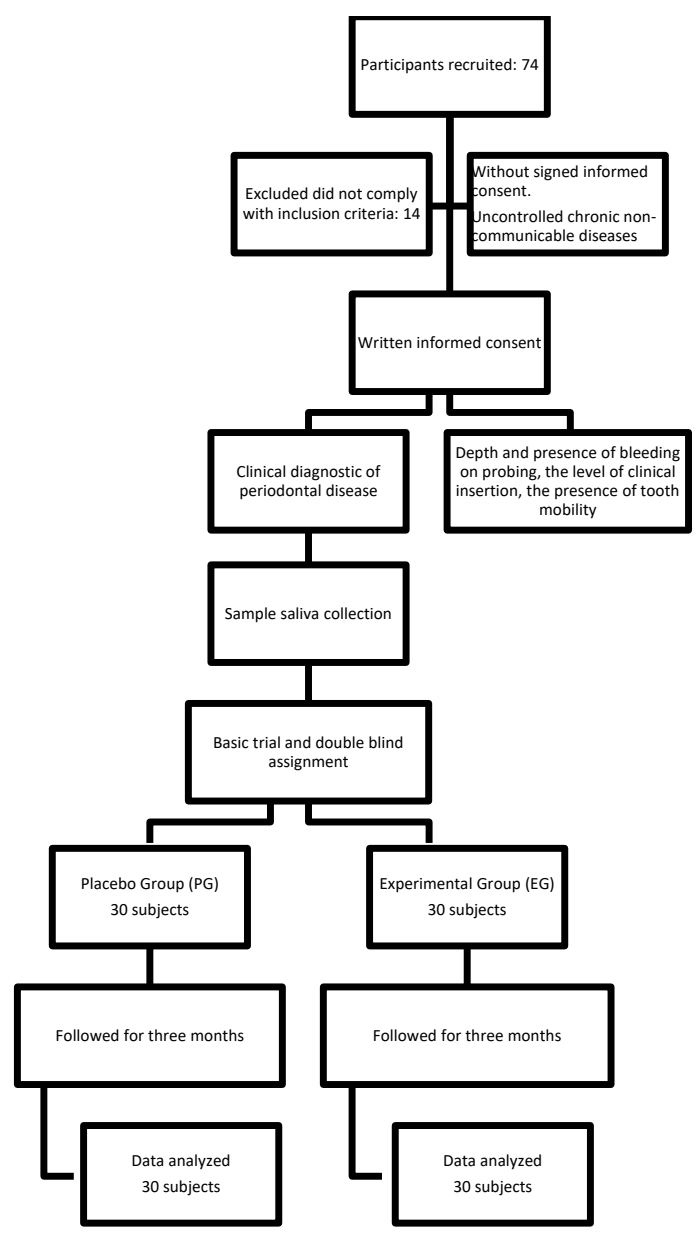

Figure 1. General scheme for study.

Saliva samples were taken before and after treatment. Lipoperoxides were quantified by the TBARS (Thiobarbituric acid reactive substance) technique, total antioxidant capacity by the $\mathrm{ABTS}^{\circledR}$ method. Superoxide dismutase enzyme (SOD) activity by the xanthine and xanthine oxidase method; inflammation markers (interleukin-1 (IL-1), IL-8, and tumor necrosis factor-alpha (TNF- $\alpha)$ ) were quantified by flow cytometry.

\subsection{Sample Size}

The sample size was calculated based on the formula for the difference of means by the lipoperoxide marker.

$\mathrm{N}=2\left[\frac{(Z \alpha-Z \beta) S D}{\mu 1-\mu 2}\right]^{2}$

Assuming that:

$z \alpha=Z$ value corresponding to alpha error $(p 0.05=1.96)$

$z \beta=Z$ value corresponding to beta error $(20 \%)$

$S D=$ Standard deviation (0.01)

$\mu 1=$ Group A mean $(0.029 \mu \mathrm{mol} / \mathrm{L})$

$\mu 2=$ Group B mean $(0.025 \mu \mathrm{mol} / \mathrm{L})$

$n=28$ per group

\subsection{Extraction and Preparation of T. lucida}

The plant specimen was collected full flowering in October, in Xochimilco, a rural area of Mexico City. It was kept on brown paper to preserve temperature and humidity. It was weighed thoroughly (flowers, leaves, and stems) and cut into proportions of approximately $10 \mathrm{~cm}$. 
The alcoholic extraction of active ingredients of T. lucida was performed under the NOM-O72 standard of the General Health Law of herbal supplements using absolute ethyl alcohol. Later, in a $250 \mathrm{~mL}$ amber glass crystal, $10 \%$ of the mother stain (extract) of T. lucida was diluted with $225 \mathrm{~mL}$ of purified water [18].

\subsection{Phytochemical Characterization}

High performance liquid chromatography (HPLC) of T. lucida analysis was performed using an Agilent Technologies 1260 Infinity Chromatograph coupled to a DAD G1315C

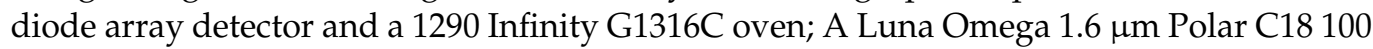
$2.1 \times 50 \mathrm{~mm}$ Phenomenex column. Chromatograms were recorded at wavelengths of 230 and $320 \mathrm{~nm}$, processed using an Open Lab software program. Chromatographic conditions were developed using $0.1 \%$ formic acid (A) and acetonitrile (B) as a mobile phase. For the sample preparation, $11 \mathrm{mg}$ of the dry extract were dissolved in $2 \mathrm{~mL}$ of a mixture of methanol: acetonitrile in a 1: 1 ratio. The injection volume was $1 \mu \mathrm{L}$, the temperature was kept constant at $35^{\circ} \mathrm{C}$, and the flow was $0.25 \mathrm{~mL} / \mathrm{min}$.

The chromatographic profile showed five main compounds compared with the literature through the retention times obtained, and using the UV spectrum at 230 and $320 \mathrm{~nm}$ it can be considered that the peaks obtained in the retention times (Rt) of 10.9, 13.7, 14.3, and 22.4 min possess the characteristic spectra of phenolic compounds with antioxidant activity. Additionally, the $7.6 \mathrm{~min}$ peak corresponds to the peak of some coumarins. Therefore, it would have anti-inflammatory activity [16,18-20] (Figure 2).

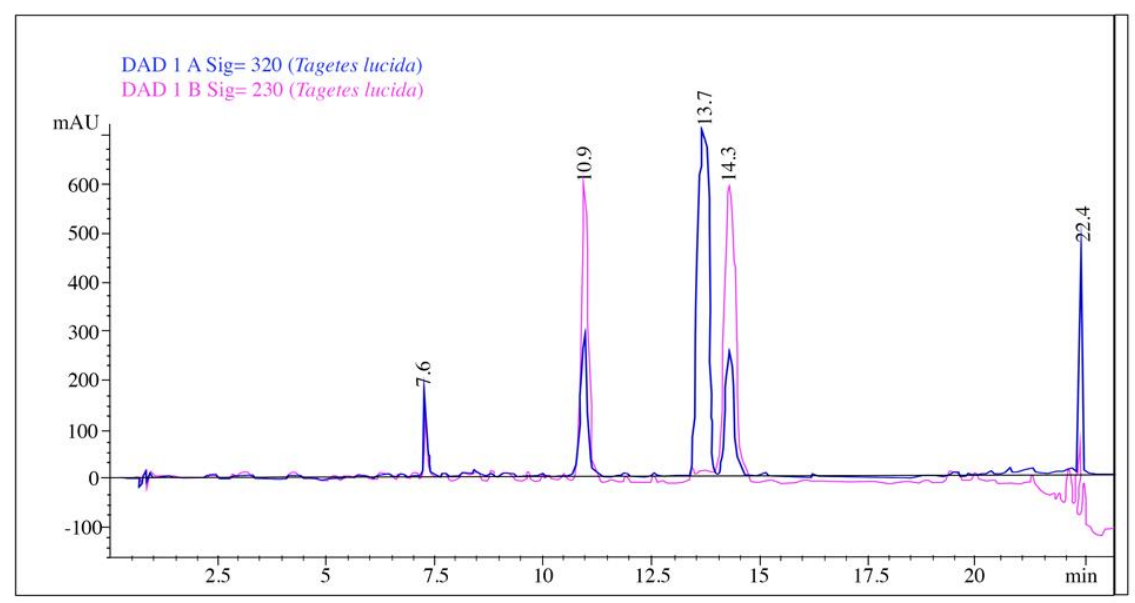

Figure 2. Chromatogram of Tagetes lucida extract at 230 and $320 \mathrm{~nm}$, showering four phenolic compounds and a coumarin-type compound with concentrations with pharmacological activity.

\subsection{Clinical Evaluation}

The probing pocket depth (PPD) of all dental organs in each individual was evaluated, using a graduated periodontal probe between teeth and gums at a standard force to measure pocket depth. The clinical attachment loss (CAL) was determined measuring the distance between the pouch base and the cement-enamel junction. To evaluate the bleeding on probing, the probe was inserted in the pocket bottom; this procedure was repeated after $30 \mathrm{~s}[21]$.

Dental mobility tests were performed with vestibular-palatine, vestibular-lingual, and mesiodistal movements, considering physiological mobility.

\subsection{Saliva Samples and Biochemical Techniques}

All participants were asked not to eat, drink, or brush their teeth $1 \mathrm{~h}$ prior to the trial, and not to consume any alcoholic beverages $24 \mathrm{~h}$ prior to sample collection. To stimulate saliva production, participants chewed a piece of paraffin wax for $7 \mathrm{~min}$. Saliva produced during the first 2 min was discarded. Then, the patients chewed the paraffin during the 
time of saliva collection until $5 \mathrm{~mL}$ [22]. Saliva samples were stabilized and conserved after centrifuged at $3000 \mathrm{rpm} \times 20 \mathrm{~min}$, kept in $400 \mu \mathrm{L}$ aliquots at $-70{ }^{\circ} \mathrm{C}$ to preserve them, and then processed. Oxidative stress was quantified using the following techniques:

\subsection{TBARS}

The TBARS assay was performed using the whole saliva according Jentzsch et al. (1996) [23]. In this assay, one molecule of malondialdehyde reacts with two molecules of thiobarbituric acid (TBA), producing a pink pigment with an absorption peak of $535 \mathrm{~nm}$. Amplification of peroxidation during the assay was prevented by adding the chain-breaking antioxidant butylated hydroxytoluene (BHT).

\subsection{Saliva Total Antioxidant Status (TAS)}

Antioxidant quantification was performed by monitoring 2,2'-azino-bis (3-ethylbenzth iazoline-6-sulfonic acid) (ABTS+) radical formation (Randox Laboratories, Ltd., Crumlin Co., UK). The antioxidants present suppressed the bluish-green staining of the ABTS+ cation, proportional to the antioxidant concentration. The reaction kinetic was measured using a colorimetric technique in an Autoanalyzer Vitalab Eclipse Merck (Dieren, The Netherlands) [24].

\subsection{Saliva Superoxide Dismutase (SOD)}

Xanthine and xanthine oxidase (XOD) were used to generate superoxide radicals, which react with 2-(4-iodophenyl)-3-(4-nitrophenyl)-5-phenyltetrazolium chloride to produce a red formazan dye. SOD activity was assessed by measuring the reaction inhibition using a commercial method (Randox Laboratories Ltd., Crumlin Co., UK). The kinetics of SOD activity was measured using a colorimetric technique in an Autoanalyzer Vitalab Eclipse Merck (Dieren, The Netherlands) [25].

\subsection{Quantification of Cytokines}

The levels of interleukin 1-beta (IL-1 $\beta$ ), interleukin 8 (IL-8), and tumor necrosis factoralpha (TNF- $\alpha$ ) were assessed in saliva aliquots by flow cytometry (CBA Kit, Human Inflammatory Cytokine, BD Biosciences, Becton, Dickinson and Company, Baltimore, MD, USA) [26].

\subsection{Statistical Analysis}

Data were analyzed using descriptive statistics, the mean and standard deviation (SD), frequencies (f), and percentages (\%). We performed a chi-square comparison test and repeated measures analysis of variance (repeated measures ANOVA) [27]. A $p$ value of $<0.05$ was considered statistically significant. $p$ values were determined using SPSS program SPSS, version 16.0.

\section{Results}

\subsection{Clinical Changes Related to Treatment}

In the clinical evaluation, after 3 months of treatment, we observed a significant improvement in the EG compared to the PG in PPD (baseline, $5.2 \pm 0.81$ vs. post-treatment, $3.1 \pm 0.43, p<0.05$ ) and CAL (baseline, $6.6 \pm 1.9$ vs. post-treatment, $2.1 \pm 1.5, p<0.05$ ) (Table 1).

Table 1. Clinical changes baseline and post-treatment by group.

\begin{tabular}{ccccccc}
\hline & \multicolumn{2}{c}{$\begin{array}{c}\text { Placebo Group } \\
(\boldsymbol{n}=\mathbf{3 0 )}\end{array}$} & \multicolumn{3}{c}{$\begin{array}{c}\text { Experimental Group } \\
(\boldsymbol{n}=\mathbf{3 0 )})\end{array}$} \\
\hline & Baseline & Post-Treatment & Differences & Baseline & Post-Treatment & Differences \\
\hline PPD $(\mathrm{mm})$ & $5.1 \pm 0.64$ & $5.7 \pm 0.87$ & $0.6 \pm 0.23$ & $5.2 \pm 0.81$ & $3.1 \pm 0.43 *$ & $-2.1 \pm 0.38$ \\
CAL $(\mathrm{mm})$ & $6.6 \pm 1.10$ & $7.4 \pm 1.30$ & $0.8 \pm 0.20$ & $6.6 \pm 1.90$ & $2.1 \pm 1.50 *$ & $-4.5 \pm 0.40$ \\
\hline
\end{tabular}

Abbreviations: PPD, probing pocket depth; CAL, clinical attachment loss. Values are means \pm SD. * Repeated measures analysis of variance $p<0.05$. 
Regarding bleeding by the dental probe and dental mobility, a significant decrease in both clinical symptoms was observed after treatment in the EG compared with PG $(p<0.001)$ (Table 2).

Table 2. Periodontal clinical changes baseline and post-treatment by group.

\begin{tabular}{|c|c|c|c|c|}
\hline & \multicolumn{2}{|c|}{$\begin{array}{l}\text { Placebo Group } \\
\quad(n=30)\end{array}$} & \multicolumn{2}{|c|}{$\begin{array}{l}\text { Experimental Group } \\
\qquad(n=30)\end{array}$} \\
\hline & Baseline & Post-Treatment & Baseline & Post-Treatment \\
\hline \multicolumn{5}{|c|}{$\operatorname{DM~f}(\%)$} \\
\hline Yes & $17(57)$ & $21(70)$ & $20(68)$ & $2(8) *$ \\
\hline No & $13(43)$ & $9(30)$ & $10(32)$ & $28(92)$ \\
\hline \multicolumn{5}{|c|}{ BOP f (\%) } \\
\hline Yes & $16(52)$ & $12(40)$ & $16(53)$ & $2(7)^{*}$ \\
\hline No & $14(48)$ & $18(60)$ & $14(47)$ & $28(93)$ \\
\hline
\end{tabular}

Abbreviations: f, frequency; DM, dental mobility; BOP, bleeding on probing. $\mathrm{X}^{2}$-test control (3 months) vs. treatment (3 months)* $p<0.0001$.

\subsection{Effect of T. lucida on Oxidative Stress Markers}

Concerning oxidative stress markers in saliva, at the end of the three-month treatment with the T. lucida mouthwash, a significant decrease in lipoperoxides levels was observed in the EG group compared with PG $(p<0.05)$. In contrast, there was an increase in both total antioxidant capacity and superoxide dismutase activity, although these were not statistically significant $(p>0.05)$ (Table 3).

Table 3. Oxidative stress markers baseline and post-treatment by group.

\begin{tabular}{|c|c|c|c|c|}
\hline & \multicolumn{2}{|c|}{$\begin{array}{l}\text { Placebo Group } \\
\quad(n=30)\end{array}$} & \multicolumn{2}{|c|}{$\begin{array}{l}\text { Experimental Group } \\
\qquad(n=30)\end{array}$} \\
\hline & Baseline & Post-Treatment & Baseline & Post-Treatment \\
\hline $\mathrm{LPO}(\mu \mathrm{mol} / \mathrm{L})$ & $0.049 \pm 0.02$ & $0.054 \pm 0.06$ & $0.056 \pm 0.03$ & $0.034 \pm 0.02 *$ \\
\hline TAS (mmol/L) & $0.55 \pm 0.39$ & $0.66 \pm 0.42$ & $0.58 \pm 0.36$ & $0.71 \pm 0.47$ \\
\hline $\mathrm{SOD}(\mathrm{IU} / \mathrm{L})$ & $1.60 \pm 0.52$ & $1.50 \pm 0.54$ & $1.56 \pm 0.52$ & $1.64 \pm 0.49$ \\
\hline
\end{tabular}

Values are means \pm SD. ${ }^{*}$ Repeated measures analysis of variance $p<0.05$. LPO: lipoperoxides TAS: total antioxidant status, SOD: superoxide dismutase.

\subsection{Effect of T. lucida on Inflammatory Markers}

A significant decrease in interleukin $1 \beta$, interleukin IL- 8 , and TNF- $\alpha$ concentration in saliva was found after three months of treatment with T. lucida compared with PG $(p<0.05)$ (Table 4$)$.

Table 4. Inflammatory markers, baseline, and post-treatment by group.

\begin{tabular}{ccccc}
\hline & \multicolumn{2}{c}{$\begin{array}{c}\text { Placebo Group } \\
(\boldsymbol{n}=\mathbf{3 0 )}\end{array}$} & \multicolumn{2}{c}{$\begin{array}{c}\text { Experimental Group } \\
(\boldsymbol{n}=\mathbf{3 0 )}\end{array}$} \\
\hline & Baseline & Post-Treatment & Baseline & Post-Treatment \\
\hline $\mathrm{IL}-1 \beta(\mathrm{pg} / \mathrm{mL})$ & $774 \pm 1332$ & $661 \pm 483$ & $871 \pm 1126$ & $462 \pm 800.9^{*}$ \\
$\mathrm{IL}-8(\mathrm{pg} / \mathrm{mL})$ & $448 \pm 343$ & $571 \pm 310$ & $827 \pm 647$ & $624 \pm 494^{*}$ \\
$\mathrm{TNF}-\alpha(\mathrm{pg} / \mathrm{mL})$ & $3.7 \pm 1.5$ & $4.4 \pm 1.6$ & $5.2 \pm 2.6$ & $3.3 \pm 0.84^{*}$ \\
\hline
\end{tabular}

Values are means \pm SD. ${ }^{*}$ Repeated measures analysis of variance $p<0.05$. IL-1 $\beta$ : interleukin $1 \beta$; IL-8: interleukin 8 ; TNF- $\alpha$ : tumor necrosis factor alpha.

\section{Discussion}

Chronic periodontitis (CP) is a degenerative and inflammatory disease with damage and loss of connective tissue, which in general is associated with the activation of 
polymorphonuclear leukocytes that generate reactive oxygen species (ROS) [28,29]. It has also been linked with physiopathological mechanisms of numerous aging-related diseases which lead to the production of ROS during inflammatory conditions [30-32]. In this sense, medicinal herbal medicine can be a therapeutic alternative in the dental field, since research has been carried out to support the use of various plant species such as T. lucida, which, due to its chemical composition, has anti-inflammatory and antioxidant properties. It could have a positive effect on chronic periodontitis, as an alternative treatment or in parallel with another dental treatment $[18,33]$.

The results showed that older adults with CP treated with the T. lucida mouthwash for 3 months had a significant decrease in concentration of lipoperoxides associated with an improvement in the signs and symptoms of CP compared to untreated older adults. This finding supports the proposal of the antioxidant effect of T. lucida [11]. Additionally, the decrease in ROS and the increase in the efficiency of the antioxidant system agree with results reported by some authors who found an association between decrease of oxidative stress and CP [34-38]. Consequently, the excess of ROS can selectively damage the proteoglycans associated with soft periodontal tissues and alveolar bone, activating nuclear factor kappa B (NF-kB) that triggers signaling cascades that activate osteoclasts, leading to inflammation [35,39-42].

On the other hand, an increase in the total antioxidant capacity and in the activity of the SOD enzyme was observed, although not statistically significant, probably due to the sample size. Similarly, there have been studies conducted with different treatments based on plant species, such as Commyphora myrrha, Mentha piperita, Bursa Pastoris, Clematis ternifolia, Timus vulgaris, and Aquillea millefolium, at different times of intervention and in some cases, changing hygienic-dietary habits of the patients [32-37]. In our study, we observed that the post-treatment concentration of lipoperoxides decreased significantly $(p \leq 0.05)$. In this regard, other studies have reported a statistically significant decrease in the concentration of lipoperoxides, when performing periodontal treatments; however, such treatments increase damage to periodontal tissues caused by the scraping and curettage procedure [43].

Likewise, some studies have shown that the salivary system is formed by some enzymes such as SOD. This enzyme is capable of increasing in response to different inflammatory diseases such as pulpitis and periodontitis. SOD is able to protect the oral cavity against the effects of ROS, which could be considered a partial compensatory response when there is oxidative stress in the cavity, and SOD represents the first defense in the antioxidant tissues [44,45].

In this work, the results of oxidative stress markers show a global improvement in the EG by decreasing lipoperoxidation, preserving the activity of SOD, and increasing the total antioxidant activity.

Regarding the levels of pro-inflammatory interleukins, it was observed that they decreased significantly in the treatment group with T. lucida, an effect due to the decrease in the periodontal infectious process. Therefore, the decrease in the secretion of bacterial lipopolysaccharides is caused by a decrease in the secretion of these interleukins of the macrophages, and consequently the decrease in osteoclastic activity and expression of adhesion molecules to the vascular endothelium [46,47].

Accordingly, some animals studies where CP has been induced and treated with some plants rich in curcumin, tannins, and phenolic compounds showed a significant decrease in $\mathrm{TNF}-\alpha$ [48].

In this sense, it is essential to consider that extracts of T. lucida have a potential antiseptic effect; this bactericidal activity decreased the microorganisms number leading to anti-inflammatory effects and decreased oxidative stress [11,14,19].

This was clinically observed with the favorable modifications found in the clinical evolution of CP in the group treated with T. lucida, since the CAL and the PPD decreased in this group $(p<0.05)$; probably due to the decrease in periodontopathogens and leukocyte infiltrate associated with the reduced concentrations of pro-inflammatory cytokines. Additionally, the decrease in periodontal pockets was probably due to the osteoclastic action 
did not continue because the secretion of IL- $1 \beta$ and TNF- $\alpha$ decreased $[49,50]$. Furthermore, mobility and gingival bleeding reduced significantly in the EG $(p<0.05)$ due to the restoration of periodontal tissue integrity and the fibroblastic protective action of $T$. lucida quercetin [50].

Finally, it is important to point out as limitations of the study: (i) the reduced sample size to measure the effect on all oxidative stress markers; (ii) the groups were not proportional by sex, consequently, the influence of this variable could not be evaluated; (iii) study follow-up was only once at 3 months, so the effectiveness over time cannot be guaranteed; (iv) the plaque index was not measured; and (v) a comparison group with a mouth rinse as the gold standard was not included, such as $0.12 \%$ chlorhexidine [51,52]. In this sense, it is advisable to carry out a longitudinal study with subsequent clinical evaluations considering the indicated limitations.

\section{Conclusions}

Our findings suggest that T. lucida has an antioxidant and anti-inflammatory effect in older adult subjects with $\mathrm{CP}$, presumably due to the presence of curcumin and quercetin contained in this plant.

Author Contributions: T.M.-C.: investigation, methodology, visualization, and writing-original draft. R.R.-U.: conceptualization, investigation, methodology, project administration, resources, supervision, writing_-original draft. M.L.-H.: data curation, formal analysis, methodology. M.R.-R.: data curation, formal analysis, methodology. V.M.M.-N.: formal analysis, writing-review and editing. All authors have read and agreed to the published version of the manuscript.

Funding: The publication of this paper was supported by a grant from the Secretaría de Educación, Ciencia, Tecnología e Innovación de la Ciudad de México CM-SECTEI/200/2020 “Red Colaborativa de Investigación Traslacional para el Envejecimiento Saludable de la Ciudad de México (RECITES)". Posgrado en Ciencias Biológicas, Universidad Nacional Autónoma de México. Consejo Nacional de Ciencia y Tecnología (Beca de Posgrado CONACYT CVU 70011).

Institutional Review Board Statement: The study was conducted according to the guidelines of the Declaration of Helsinki, and approved by Ethics Committee of Universidad Nacional Autónoma de México (UNAM), Zaragoza Campus (protocol code FESZ/DEPI/325/16).

Informed Consent Statement: Informed consent was obtained from all subjects involved in the study.

Data Availability Statement: The data presented in this study are available on request from the corresponding author. The data are because they are owned by UNAM.

Conflicts of Interest: The authors declare no conflict of interest.

\section{References}

1. Dahiya, P.; Kamal, R.; Gupta, R.; Bhardwaj, R.; Chaudhary, K.; Kaur, S. Reactive oxygen species in periodontitis. J. Indian Soc. Periodontol. 2013, 17, 411-416. [CrossRef]

2. Chapple, I.L.; Matthews, J.B. The role of reactive oxygen and antioxidant species in periodontal tissue destruction. Periodontology 2007, 43, 160-232. [CrossRef]

3. Kim, S.C.; Kim, O.S.; Kim, O.J.; Kim, Y.J.; Chung, H.J. Antioxidant profile of whole saliva after scaling and root planning in periodontal disease. J. Periodontal. Implant. Sci. 2010, 40, 164-171. [CrossRef]

4. Brock, G.R.; Butterworth, C.J.; Matthews, J.B.; Chapple, I.L. Local and systemic total antioxidant capacity in periodontitis and health. J. Clin. Periodontol. 2004, 31, 515-521. [CrossRef]

5. Pihlstrom, B.L.; Michalowicz, B.S.; Johnson, N.W. Periodontal diseases. Lancet 2005, 366, 1809-1820. [CrossRef]

6. Islas-Granillo, H.; Borges-Yañez, S.A.; Navarrete-Hernández, J.J.; Veras-Hernández, M.A.; Casanova-Rosado, J.F.; Minaya-Sánchez, M.; Casanova-Rosado, A.J.; Fernández-Barrera, M.A.; Medina-Solís, C.E. Indicators of oral health in older adults with and without the presence of multimorbidity: A cross-sectional study. Clin. Interv. Aging. 2019, 14, 219-224. [CrossRef]

7. Aslani, A.; Ghannadi, A.; Najafi, H. Desing, formulation and evaluation of a mucoadhesive gel from Quercus brantii L. and Coriandrum sativum L. as periodontal drug delivery. Adv. Biomed. Res. 2013, 2, 21. [CrossRef] [PubMed]

8. Yagnini, J.; Shahabooei, M.; Aslani, A.; Zadeh, M.R.; Kiani, S.; Naghsh, N. Efficacy of local- drug delivery gel containing extracts of Quercus brantii and Coriandrum sativum as an adjunct to scaling and root planning in moderate chronic periodontitis patients. J. Res. Pharm. Pract. 2014, 3, 67-71. 
9. Kumar, G.; Jalaluddin, M.; Rout, P.; Mohanty, R.; Dileep, C.L. Emerging trends of herbal care in dentistry. J. Clin. Diagn. Res. 2013, 7, 1827-1829.

10. Regalado, E.L.; Fernández, M.D.; Pino, J.A.; Mendiola, J.; Echemendia, O.A. Chemical composition and biological properties of the leaf essential oil of Tagetes lucida Cav. from Cuba. J. Essent. Oil. Res. 2011, 23, 63-67. [CrossRef]

11. Salehi, B.; Valussi, M.; Morais-Braga, M.F.B.; Carneiro, J.N.P.; Leal, A.L.A.B.; Coutinho, H.D.M.; Vitalini, S.; Kręgiel, D.; Antolak, H.; Sharifi-Rad, M.; et al. Tagetes spp. essential oils and other extracts: Chemical characterization and biological activity. Molecules 2018, 23, 2847. [CrossRef] [PubMed]

12. Facultad de Estudios Superiores Zaragoza. Tagetes lucida Cav. Herbario de la FES ZARAGOZA-UNAM con el número de colección 156999. 2017. Available online: https:/ / www.zaragoza.unam.mx/herbario/ (accessed on 16 October 2017).

13. U.S. FUD and Drug Administration. Substance Registration System. Unique Ingredient Identifier UNII: N4052J8NFR; 2019. Available online: https:/ / fdasis.nlm.nih.gov/srs/unii/N4052J8NFR (accessed on 19 August 2019).

14. Céspedes, C.L.; Avila, J.G.; Martínez, A.; Serrato, B.; Calderón-Mugica, J.C.; Salgado-Garciglia, R. Antifungal and antibacterial activities of Mexican tarragon (Tagetes lucida). J. Agric. Food Chem. 2006, 54, 3521-3527. [CrossRef]

15. Bonilla-Jaime, H.; Guadarrama-Cruz, G.; Alarcon-Aguilar, F.j.; Limón-Morales, O.; Vazquez-Palacios, G. Antidepressant-like activity of Tagetes lucida Cav. is mediated by 5-HT(1A) and 5-HT(2A) receptors. J. Nat. Med. 2015, 69, 463-470. [CrossRef] [PubMed]

16. Pérez-Ortega, G.; González-Trujano, M.E.; Ángeles-López, G.E.; Brindis, F.; Vibrans, H.; Reyes-Chilpa, R. Tagetes lucida Cav.: Ethnobotany, phytochemistry and pharmacology of its tranquilizing properties. J. Ethnopharmacol. 2016, 181, 221-228. [CrossRef]

17. Guadarrama-Cruz, G.; Alarcón-Aguilar, J.; Vaga-Ávila, E.; Vázquez-Palacios, G.; Bonilla-Jaime, H. Antidepressant-like effect of Tagetes lucida Cav. extract in rats: Involvement of the serotonergic system. Am. J. Chin. Med. 2012, 40, 753-768.

18. Aquino, R.; Cáceres, A.; Morelli, S.; Luca Rastrelli, L. An extract of Tagetes lucida and its phenolic constituents as antioxidants. J. Nat. Prod. 2002, 65, 1773-1776. [CrossRef]

19. Monterrosas-Brisson, N.; Herrera-Ruiz, M.; Jiménez-Ferrer, E.; Bahena-Pérez, R.; Avilés-Flores, M.; Fuentes-Mata, M.; MartínezDuncker, I.; González-Cortazar, M. Anti-inflammatory activity of coumarins isolated from Tagetes lucida Cav. Nat. Prod. Res. 2019. [CrossRef]

20. Scull, R.; Gutiérrez, Y.I.; Sánchez, A.; Montes, A. Análisis farmacognóstico de Tagetes lucida Cav. y sus extractos hidroalcohólicos. Rev. Cienc. Farm. Aliment. 2016, 2, 1-13.

21. Ramfjord, S.P. The Periodontal Disease Index (PDI). J. Periodontol. 1967, 38, S602-S610. [CrossRef]

22. Arana, C.; Cutando, A.; Ferrera, M.J.; Gómez-Moreno, G.; Worf, C.V.; Bolaños, M.J.; Escames, G.; Acuña-Castroviejo, D. Parameters of oxidative stress in saliva from diabetic and parenteral drug addict patients. J. Oral Pathol Med. 2006, 35, 554-559. [CrossRef]

23. Jentzsch, A.M.; Bachmann, H.; Fürst, P.; Biesalski, H.K. Improved analysis of malondialdehyde in human body fluids. Free Radic. Biol. Med. 1996, 20, 251-256. [CrossRef]

24. Mendoza-Núñez, V.M.; Ruiz-Ramos, M.; Sánchez-Rodríguez, M.A.; Retana-Ugalde, R.; Muñoz-Sánchez, J.L. Aging-related oxidative stress in healthy humans. Tohoku J. Exp. Med. 2007, 213, 261-268. [CrossRef]

25. Karim, S.; Pratibha, P.K.; Kamath, S.; Bhat, G.S.; Kamath, U.; Dutta, B.; Sharma, N.; Archana, B.; Bhat, K.M.; Guddattu, V. Superoxide dismutase enzyme and thiol antioxidants in gingival crevicular fluid and saliva. Dent. Res. J. (Isfahan) 2012, 9, 266-272.

26. Cook, E.B.; Stahl, J.L.; Lowe, L.; Chen, R.; Morgan, E.; Wilson, J.; Varro, R.; Chan, A.; Graziano, F.M.; Barney, N.P. Simultaneous measurement of six cytokines in a single sample of human tears using microparticle-based flow cytometry: Allergics vs. non-allergics. J. Immunol. Methods. 2001, 254, 109-118. [CrossRef]

27. Park, E.; Cho, M.; Ki, C.S. Correct use of repeated measures analysis of variance. Korean J. Lab. Med. 2009, 1, 1-9. [CrossRef]

28. Khiste, S.V.; Ranganath, V.; Nichani, A.S.; Rajani, V. Critical analysis of biomarkers in the current periodontal practice. J. Indian Soc. Periodontol. 2011, 15, 104-110. [CrossRef]

29. Kinane, D.F.; Marshall, G.J. Periodontal manifestations of systemic disease. Aust. Dent. J. 2001, 46, 2-12. [CrossRef] [PubMed]

30. Grossi, S.G.; Genco, R.J. Periodontal disease and diabetes mellitus: A two-way relationship. Ann. Periodontol. 1998, 3, 51-61. [CrossRef] [PubMed]

31. Battino, M.; Bullon, P.; Wilson, M.; Newman, H. Oxidative injury and inflammatory periodontal diseases: The challenge of anti-oxidants to free radicals and reactive oxygen species. Crit. Rev. Oral Biol. Med. 1999, 10, 458-476. [CrossRef] [PubMed]

32. Cannizzo, E.S.; Clement, C.C.; Sahu, R.; Follo, C.; Santambrogio, L. Oxidative stress, inflamm-aging and immunosenescence. J. Proteomics. 2011, 74, 2313-2323. [CrossRef]

33. Guadarrama-Cruz, G.; Alarcon-Aguilar, F.J.; Lezama-Velasco, R.; Vázquez-Palacios, G.; Bonilla-Jaime, H. Antidepressant-like effects of Tagetes lucida cav. In the forced swimming test. J. Ethnopharmacol. 2008, 120, 277-281. [CrossRef] [PubMed]

34. Atabay, V.E.; Lutfioğlu, M.; Avci, B.; Sakallioglu, E.E.; Aydoğdu, A. Obesity and oxidative stress in patients with different periodontal status: A case-control study. J. Periodontal. Res. 2017, 52, 51-60. [CrossRef] [PubMed]

35. Wei, D.; Zhang, X.L.; Wang, Y.Z.; Yang, C.X.; Chen, G. Lipid peroxidation levels, total oxidant status and superoxide dismutase in serum, saliva and crevicular fluid in chronic periodontitis patients before and after periodontal therapy. Aust. Dent. J. 2010, 55, 70-78. [CrossRef] [PubMed]

36. Guentsch, A.; Preshaw, P.M.; Bremer-Streck, S.; Klinger, G.; Glockmann, E.; Sigusch, B.W. Lipid peroxidation and antioxidant activity in saliva of periodontitis patients: Effect of smoking and periodontal treatment. Clin. Oral Investig. 2008, 12, 345-352. [CrossRef] 
37. de Oliveira, J.S.; Pinto, M.E.; Santana, L.A.; Pinto, A.S.; di Lenardo, D.; Vasconcelos, D.F. Biological effects of medicinal plants on induced periodontitis: A systematic review. Int. J. Dent. 2016, 3719879. [CrossRef]

38. Tsai, C.C.; Chen, H.S.; Chen, S.L.; Ho, Y.P.; Ho, K.Y.; Wu, Y.M. Lipid peroxidation a possible role in the induction and progression of chronic periodontitis. J. Periodont. Res. 2005, 40, 378-384. [CrossRef]

39. Waddington, R.J.; Moseley, R.; Embery, G. Periodontal disease mechanisms: Reactive oxygen species: A potential role in the pathogenesis of periodontal diseases. Oral Dis. 2000, 6, 138-151. [CrossRef]

40. Rittié, L.; Monboisse, J.C.; Gorisse, M.C.; Gillery, P. Malondialdehyde binding to proteins dramatically alters fibroblast functions. J. Cell Physiol. 2002, 191, 227-236. [CrossRef]

41. Moore, S.; Calder, K.A.; Miller, N.J.; Rice-Evans, C.A. Antioxidant activity of saliva and periodontal disease. Free Radic. Res. 1994, 21, 417-425. [CrossRef]

42. Jimi, E.; Aoki, K.; Saito, H.; D’Acquisto, F.; May, M.J.; Nakamura, I.; Sudo, T.; Kojima, T.; Okamoto, F.; Fukushima, H.; et al. Selective inhibition of NF-kappa B blocks osteoclastogenesis and prevents inflammatory bone destruction in vivo. Nat. Med. 2004, 10, 617-624. [CrossRef]

43. Hrishi, T.S.; Kundapur, P.P.; Naha, A.; Thomas, B.S.; Kanath, S.; Bhat, G.S. Effect of adjunctive use of Green tea dentifrice in periodontitis patients-A randomized controlled pilot study. Int. J. Dent. Hyg. 2016, 14, 178-183. [CrossRef]

44. Mascitti, M.; Coccia, E.; Vignini, A.; Aquilanti, L.; Santarelli, A.; Salvolini, E.; Sabbatinelli, J.; Mazzanti, L.; Procaccini, M.; Rappelli, G. Anorexia, oral health and antioxidant salivary system: A clinical study on adult female subjects. Dent. J. 2019, 7, 60. [CrossRef]

45. Tóthová, L.; Kamodyová, N.; Červenka, T.; Celec, P. Salivary markers of oxidative stress in oral diseases. Front. Cell Infect. Microbiol. 2015, 5, 73. [CrossRef]

46. Yang, H.; Wen, Q.; Xue, J.; Ding, Y. Alveolar bone regeneration potential of a traditional chinese medice, Bu-Shen-Gu-Chi-Wan, in experimental periodontitis. J. Periodontal. Res. 2014, 49, 382-389. [CrossRef]

47. Moradi, J.; Abbasipour, F.; Zaringhalam, J.; Maleki, B.; Ziaee, N.; Khodadoustan, A.; Janahmadi, M. Anethole a medicinal plant compound, decreases the production of pro- inflammatory TNF- $\alpha$ and IL-1 $\beta$ in rat model of LPS-induced periodontitis. Iran. J. Pharm Res. 2014, 13, 1319-1325. [PubMed]

48. Elburki, M.S.; Rossa, C.; Guimaraes, M.R.; Goodenough, M.; Lee, H.M.; Curylofo, F.A.; Zhang, Y.; Johnson, F.; Golub, L.M. A novel chemically modified curcumin reduces severity of experimental periodontal disease in rats: Initial observations. Mediat. Inflamm. 2014, 959471. [CrossRef] [PubMed]

49. Sulistyani, H.; Fujita, M.; Nakazawa, F. Effect of roselle caliyx extract on gingipain activity, production of inflammatory cytokines, and oral bacterial morphology. J. Microbiol. Biotech. Food Sci. 2016, 6, 961-965. [CrossRef]

50. Zhou, T.; Chen, D.; Li, Q.; Sun, X.; Song, Y.; Wang, C. Curcumin inhibits inflammatory response and bone loss during experimental periodontitis in rats. Acta Odontol. Scand. 2013, 71, 349-356. [CrossRef]

51. Gunsolley, J.C. Clinical efficacy of antimicrobial mouthrinses. J. Dent. 2010, 38 (Suppl. 1), S6-S10. [CrossRef]

52. Barbosa, S.I.; Coury, S.C.H.; Collantes, D.I.E. Can mouth washes containing chlorhexidine $0.12 \%$ be used as synonym of a water solution of chlorhexidine $0.12 \%$ ? Braz. J. Pharm. Sci. 2015, 51, 2. [CrossRef] 